\title{
Influence of hypothyroidism on renal function of lithium-treated patients
}

This article was published in the following Dove Press journal:

Neuropsychiatric Disease and Treatment

23 December 2015

Number of times this article has been viewed

\author{
Roberto Lozano \\ Reyes Marín \\ María-Jesús Santacruz \\ Pharmacy Department, Aragones \\ Health Service, Zaragoza, Spain
}

Correspondence: Roberto Lozano Servicio Farmacia, Hospital Real de Nuestra Sra de Gracia, D Roberto Lozano Ortiz, C/Ramon y Cajal 60, 50004 Zaragoza, Spain

Email rlozano@salud.aragon.es

\section{Dear editor}

Several studies have shown that lithium maintenance treatment for bipolar disorder (BD) is associated with chronic kidney disease (CKD). ${ }^{1-3}$ Three recent and large controlled studies concluded that lithium treatment, within recommended serum levels, may increase the risk of induced end-stage renal disease by twofold ${ }^{1,2}$ or, alternatively, CKD is associated with BD independent of drug treatment. ${ }^{3}$ Moreover, review of the safety data on lithium shows a $0-5 \mathrm{~mL} / \mathrm{min}$ reduction in glomerular filtration rate and a clear reduction in urinary concentrating capacity, during an observation period of 1 year. ${ }^{4}$

However in any case, it should not be excluded the possibility that these associations were a result of bias. In this sense, because the risk of developing thyroid disorders, which is probably the main safety concern of lithium treatment, we would like to highlight the prevalence of hypothyroidism among BD patients as an important possible confounding variable for the associations between lithium treatment and CKD.

Indeed, we know that lithium produces thyroid dysfunction (eg, raised thyroidstimulating hormone and decreased free thyroxine, among other alterations $)^{4,5}$ in a high proportion of patients. We also know that there is a close relationship between thyroid and renal function, with hypothyroid patients displaying elevated serum creatinine levels, characterized by slower and incomplete recovery after prolonged periods of severe hypothyroidism, and reductions in glomerular filtration rate. ${ }^{6}$ These are the main thyroid-related alterations in renal function.

In summary, lithium produces renal dysfunction, which manifests diabetes insipidus and reduction of urine-concentrating ability as the most common renal complications of lithium-derived therapy. Diabetes insipidus, initially reversible upon lithium withdrawal, may become irreversible as a result of structural damage over time. ${ }^{4}$

Moreover, findings from some authors support a link between mood disorders and thyroid dysfunction, such as higher thyrotropin-releasing hormone stimulated thyroid-stimulating hormone levels observed in naïve BD-II patients, as a differential biological feature, ${ }^{7}$ among others. ${ }^{8-10}$

Finally, to continue the above described relationships between thyroid function, renal function and lithium, it is necessary to point out that overt and/or subclinical hypothyroidism and/or diabetes insipidus, two of the most important lithium-induced secondary effects, can be managed entirely by dose reduction, although combination therapy or lithium-substitution could be necessary in some cases. ${ }^{2}$

In the context of there being a close relationship between $\mathrm{BD}$ and thyroid-alterations, between renal and thyroid function, and between lithium treatment and hypothyroidism, 
Dove Medical Press encourages responsible, free and frank academic debate. The content of the Neuropsychiatric Disease and Treatment 'letters to the editor' section does not necessarily represent the views of Dove Medical Press, its officers, agents, employees, related entities or the Neuropsychiatric Disease and Treatment editors. While all reasonable steps have been taken to confirm the content of each letter, Dove Medical Press accepts no liability in respect of the content of any letter, nor is it responsible for the content and accuracy of any letter to the editor.

Neuropsychiatric Disease and Treatment

Dovepress

\section{Publish your work in this journal}

Neuropsychiatric Disease and Treatment is an international, peerreviewed journal of clinical therapeutics and pharmacology focusing on concise rapid reporting of clinical or pre-clinical studies on a range of neuropsychiatric and neurological disorders. This journa is indexed on PubMed Central, the 'PsycINFO' database and CAS, and is the official journal of The International Neuropsychiatric Association (INA). The manuscript management system is completely online and includes a very quick and fair peer-review system, which is all easy to use. Visit http://www.dovepress.com/testimonials.php to read real quotes from published authors.

Submit your manuscript here: http://www.dovepress.com/neuropsychiatric-disease-and-treatment-journal 